\title{
Improvement Of Quality Management Level In Construction Company Using EFQM Model
}

Jozef Gašparík

Faculty of Civil Engineering,

Slovak University of Technology,

Bratislava, Slovakia

jozef.gasparik@stuba.sk.
DOI 10.5592/otmcj.2014.1.5 Research paper

\section{Keywords}

Quality, Excellence Model, Construction Organization

\author{
Veronika Gašparíková \\ Institute of Management, \\ Slovak University of Technology, \\ Bratislava, Slovakia \\ veronika.gasparikova@stuba.sk.
}

\author{
Helena Ellingerová \\ Faculty of Civil Engineering, \\ Slovak University of Technology, \\ Bratislava, Slovakia \\ helena.ellingerova@stuba.sk.
}

THE PURPOSE OF THIS CONTRIBUTION IS TO INCREASE QUALITY LEVEL OF CONSTRUCTION ORGANIZATION APPLYING THE EFQM (EUROPEAN FOUNDATION FOR QUALITY MANAGEMENT) EXCELLENCE MODEL. IT PROVIDES ANALYSIS OF CURRENT QUALITY MANAGEMENT TRENDS, DEFINES EFQM MODEL STRUCTURE, CRITERIA AND POSSIBILITIES OF ITS INTRODUCTION IN CONSTRUCTION COMPANIES. The purpose of this contribution is also proposal of electronic manual and automated system of evaluation the criteria and sub-criteria of EFQM model by company management and also by external auditors. Selected scientific methods of problem solution can be divided into two main groups: empirical and logic (scientific analysis and synthesis). Empirical methods are applied to an electronic survey that aimed to determine knowledge of the EFQM model and its use in practice among organizations operating in Slovakia. The logical method was utilized for the problem solving analysis and synthesis. Application of the methodology and manual enables in a short time to evaluate company quality management level and to identify opportunities for continually quality improvement in construction company. 


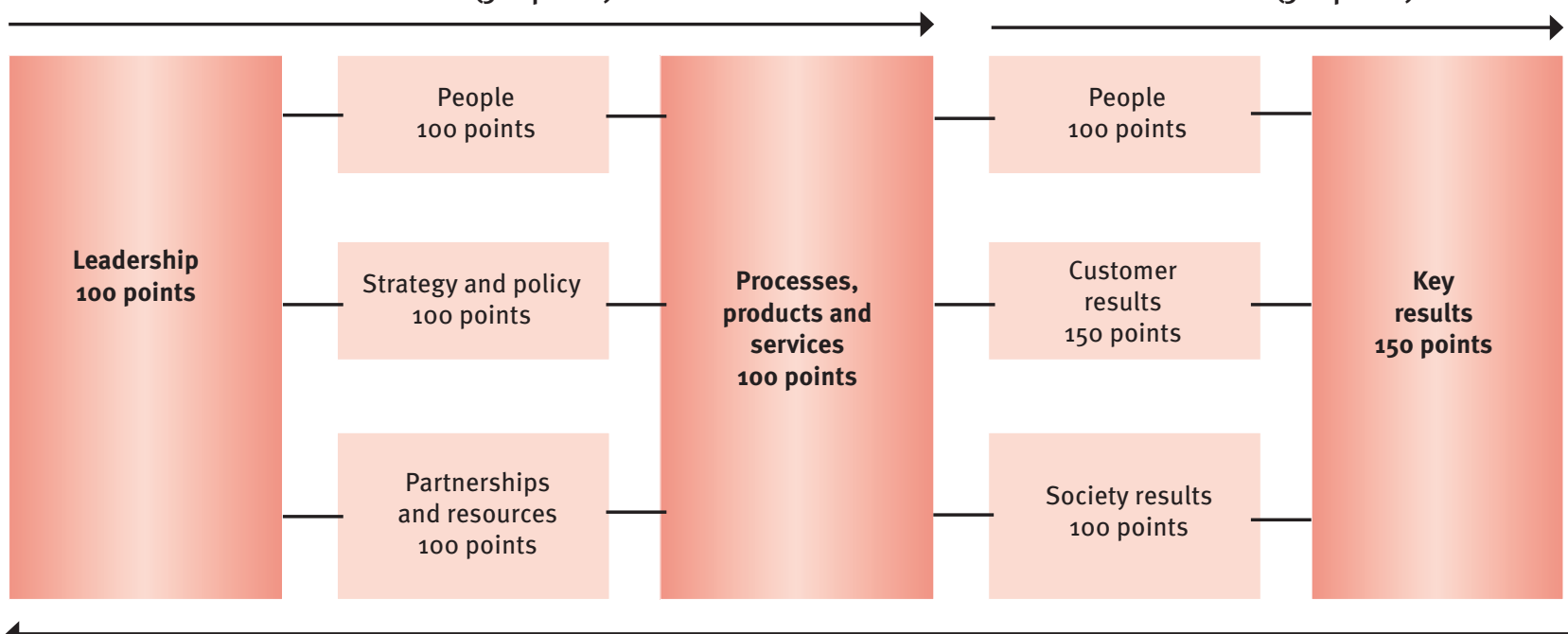

LEARNING, CREATIVITY AND INNOVATION

Figure 1. EFQM Model Structure (last revision in year 2010) (Source: EFQM, 2010)

\section{INTRODUCTION}

The EFQM excellence model is an European model based on Total Quality Management - TQM (Oakland, 2003). It is designed for all organizations that are interested in continuous improvement and progress towards excellence. The main purpose of the EFQM model is self-assessment of the organization in order to achieve continuous improvement of quality. It helps identify strengths and opportunities for improvement and encourages solutions. It allows for an independent view on the organization and its functioning (Paulová et al., 2008).

The EFQM model is a basis for assessment and evaluation of a business aspiring to receive the European Quality Award (EQA), but also the National Quality Award of the Slovak Republic. In order to win the EQA, the model must be applied for at least three years and yield the corresponding results.

The EFQM model may be used in any business as well as any government organization (however, the Common Assessment Framework - the CAF model is specially designed for public administration) (EFQM, 2003). There are several literature sources, which describe the structure of EFQM model and offer methodology, how to implement and evaluate it, but for customers are very brief and hard understood. Therefore we decided in our research work to propose integrated electronic manual, which will offer to construction company complex and total information concerning the implementation and evaluation of all criteria of EFQM model. Our electronic manual contains total 9 criteria, 32 sub-criteria and 121 sub-sub-criteria of EFQM model (Gašparík et al., 2012). Users of this manual can self-evaluate own activity in a given sub-criterion and using automated system (software) determine point value of quality level (see next chapters).

\section{EFQM model structure and features}

The EFQM model was created by the European Foundation for Quality Management (EFQM), which was founded in 1988. Its establishment involved fourteen large European corporations (Hakes, 2007). The aim of the foundation was to create a model based on Total Quality Management (TQM) in order to achieve excellence in European companies and make them competitive in comparison with the U.S. and Japanese companies in the global market. Society-wide recognition of quality in the USA - Malcolm Baldridge National Quality Award (NIST, 2003) and Japan - Deming Application Prize (JUSE, 2003) proved that the application of TQM models delivers measurable business results to organizations. The EFQM model first appeared in 1991 and it was called The European Model for Business Excellence (Porter et al., 2004). It was innovated in 1999 and it became more universal and applicable in a larger number of organizations. For public administration, the CAF (Common Assessment Framework) model was developed. It was launched in 2000 and revised in 2002.

The EFQM model is based on 9 criteria: leadership, policy and strategy, people, partnerships and resources, processes, customer results, people results and key performance results (Paulová et al., 2008). The first 5 criteria are enablers (what the organization has got) and the remaining 4 criteria are results (what the organization achieves). All criteria are divided into sub and sub-sub-criteria. The diagram of the model, together with score for each criterion is shown in Figure 1 (first page of our contribution). The direction 
of arrows shows the dynamic nature of the model. Innovation and learning help improve enablers, which leads to improved results. This process is continuous. Criteria and sub-criteria of the model are very sophisticated and deal with all areas of the organization, even with the environment surrounding it. The model emphasizes the ethical principle crucial for those who are exceptional.

\section{Survey Concerning The EFQM Model Implementation}

The survey concerning the EFQM model implementation has been carried out during three months in year 2011 by the form of electronic and anonymous questionnaire. There were surveyed 160 construction companies in Slovakia of all sizes. The questionnaire completed 36 of them.

The issues were identified about whether the model has been applied for excellence in the organization, the purpose of its application (or the reasons not to apply it), as well as interest of the construction company to introduce the EFQM model in the future. Graphical interpretation of some of the responses is shown in Figure 2.

The results obtained by survey shows that the EFQM excellence model and its application in practice in Slovakia are still relatively new, unexplored issues. Most companies do not exclude its application in the

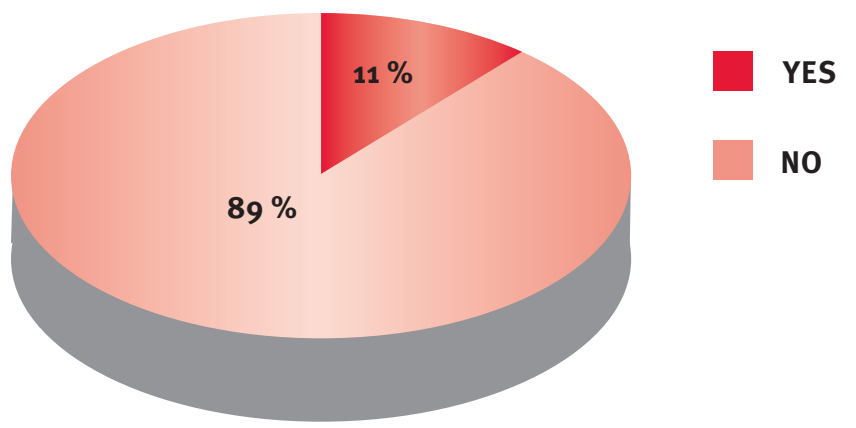

Figure 2. Application of the EFQM model at present or in the past in surveyed companies (Source: Gašparík, 2012) future, but they need much more necessary information about this model and effective training process. The solutions contained at this contribution can be helpful for the performance of the EFQM model to organizations, which have aims to continually improve their quality management level and implement maximum positive effects in future activities.

Problems and areas for improvement regarding the EFQM model application in construction organizations

The study of the EFQM model through consultations with trainers in the area of Quality Management and our own knowledge concerning this area of interest made us aware of areas for improvement and problems currently faced by Slovak companies striving for excellence when implementing the EFQM model. Application of the EFQM model in Slovak organizations is currently not a very frequent activity. Although the model seems simple, its application is a complex process in terms of time and resources. The EFQM model can be described as a higher form of quality management in organizations. It is starting to be implemented mostly by organizations, which have successfully passed the introduction and certification of the Quality Management System (QMS) according to ISO 9001 and look for other ways how to improve the quality of their products.

However, the management in most organizations fails to realize that this approach to improving the quality is not as simple as it seems at the first sight. Although the nine main criteria of the EFQM seem like they were encountered when building the QMS, the EFQM model contains a series of sub-criteria (32), which require a very detailed description of the functioning of the organization and many of the sub-criteria are often misunderstood by the management. Thus, the enthusiasm with which the management welcomes the introduction of the EFQM model begins to fade when the model is implemented in practice. A deeper study of the EFQM model makes directors come to conclusion that the whole process is too bureaucratic. Organizations often meet the EFQM requirements, but fail to record their results sufficiently and as required. When aspiring to the National Quality Award of the Slovak Republic or the European Quality Award, the company has to prepare a self-assessment report according criteria of the EFQM model. The preparation of the selfassessment report is an extremely complex and time-consuming process and requires involvement of key employees from all areas of business. Incorrect definition of processes and results in the self-assessment report may result in a low score of an otherwise successful organization from the professional EFQM auditors. This leads to disappointment, conflicts and rejection of the whole process.

The path towards excellence according to the EFQM model is a long-term process that must be upheld by the whole business from the top management to the last employee. If only the top management desires the introduction of the EFQM model and then delegates the application duties to employees - failing to properly explain its effects - it encounters resistance and the process is doomed. 
The current competitive environment in the global marketplace requires organizations to continuously improve quality. This applies not only to products, but also to processes and management. Today, it is often not enough to satisfy customer needs, but it is necessary to exceed them. This requires excellence in organizations. The EFQM excellence model understanding and effective implementation is one of the tools that can help organizations on their path of improving and achieving a lasting success.

\section{Methodology For The EFQM Model Application In Organization}

During the research work in this area, we propose a methodology for application of the EFQM model, which is proposed especially for manufacturing organizations, which have developed and implemented Quality Management System (QMS) according to standards ISO 9001 and plan further development and improvement of the existing management system using the model EFQM. Steps of the methodology are illustrated in Figure 3.

The methodology is designed in conjunction with manual and automated self-assessment system to enable the organization to apply the EFQM model in less time and evaluate their performance level and effectiveness by more transparent way. The methodology enables to get an idea of what is necessary to do in the process of EFQM model application. The actual implementation of the methodology and the manual is designed to avoid confusion and unnecessary complexity requiring to start again and resulting in the time loss.

\section{Used scientific methods}

Selected scientific methods of problem solution can be divided into two main groups: empirical and logic (scientific analysis and synthesis). Empirical methods are applied to an electronic survey that aimed to determine knowledge of

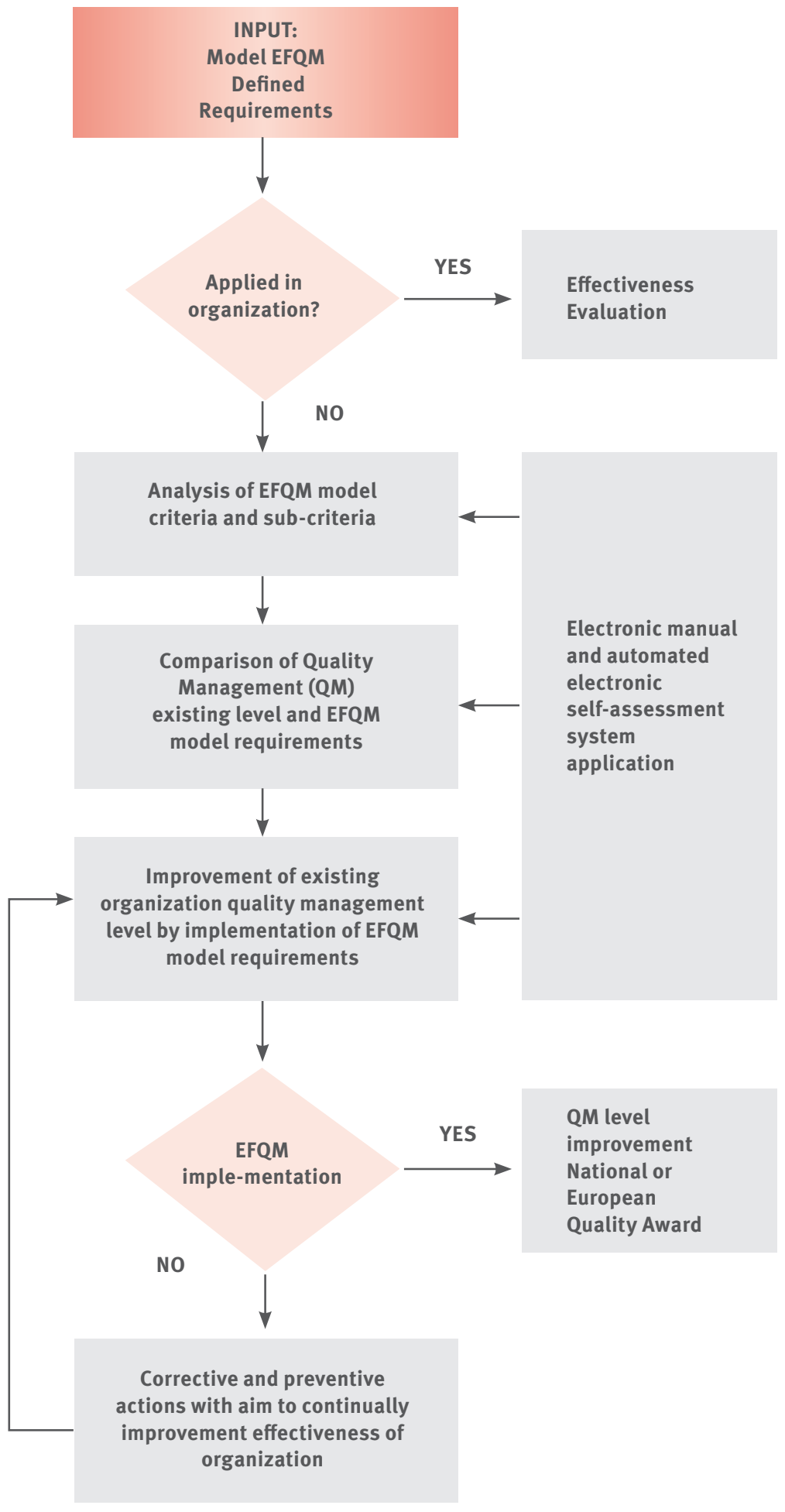

Figure 3. Steps to apply EFQM model in organization

(Source: Gašparík, 2012)

the EFQM model and its use in among organizations operating in Slovakia. The logical method was utilized for the problem solving analysis and synthesis.
Methods of scientific analysis were used to evaluate the current issue of Quality Management level and EFQM implementation in construction sector, 


\begin{tabular}{|l|l|l|}
\hline Activity is: & Description & Evaluation \% \\
\hline P (planned) & Organization plans the activity to apply & 10 \\
\hline D (done) & Activity is implemented & 15 \\
\hline C (checked) & Organization checks the effects & 20 \\
\hline A (acted) & $\begin{array}{l}\text { In a case of positive effects activity is used in } \\
\text { practice }\end{array}$ & 25 \\
\hline B (benchmarked) (Zairi, 1998), (Bendell, 1993) & $\begin{array}{l}\text { Organization compares the activity with best } \\
\text { organization in market }\end{array}$ & 30 \\
\hline
\end{tabular}

Table 1. Evaluation of activity level application according to requirements of EFQM model sub-criterion in organization

(Source: Gašparík, 2012)

\begin{tabular}{|c|l|}
\hline Level of fulfilling & Description \\
\hline 0 & There is no evidence to fulfill the requirements \\
\hline 0,25 & There exist indicators of compliance requirements \\
\hline 0,5 & Partial evidence of requirement fulfilling \\
\hline 0,75 & Significant evidence of require-ment fulfilling \\
\hline 1 & Clear evidence of requirement fulfilling \\
\hline
\end{tabular}

Table 2. Level of EFQM model sub-criterion fulfilling in a given phase of application

(Source: Gašparík, 2012)

to analyze criteria and sub-criteria of the EFQM model, to explore the possibilities of applying the EFQM model in construction organizations and to examine the existing systems of assessment under the EFQM model. Scientific synthesis method was used during the process of EFQM model development and implementation including the creation of electronic manual and during the process of automated evaluation system of construction company quality management level.

\section{Manual For The EFQM Model Implementation}

Electronic manual is designed on the basis of the EFQM model criteria and sub-criteria requirements and helps organizations to understand and apply the EFQM model and evaluate their own performance and effectiveness in a shorter time. The structure of the proposed manual consists of these main parts:

- the analysis of EFQM model requirements defined by criteria and subcriteria and determine the existing quality level of the organization and opportunities for improvement,

- self-assessment system of organization quality management level using the criteria and sub-criteria of the EFQM model by electronic automated system.

The evaluation system of the EFQM model criteria

The EFQM model consists of prediction and result parts. For each of them is in the manual suggested a specific method of evaluation. In this paper we provide an example evaluation of prediction part of the EFQM model.

In the process of self-assessment of the organization is for each of the manual requirements of prediction part of the EFQM model selected phase of applications based on the Deming cycle (Table 1) and the performance level (Table 2).

The selected phase applications and performance levels are the basis for calculating the assessment for the achievement of the criterion and sub-criterion requirement. Position in the current phase of the application assumes management of the previous phases. If the company in meeting this requirement found for example in phase "act" with the degree to 0.5 , the overall percentage achieved in meeting this requirement are:

$1 \times 10+1 \times 15+1 \times 20+0,5 \times 25=57.5(\%)$ (1) PLAN DO CHECK ACT

By this way is calculated the percentages evaluations for all requirements. 
The percentage evaluation of each sub-criterion is the weighted average of achieved percentage values for each of its requirements, and a set of weights represents the coefficients of importance.

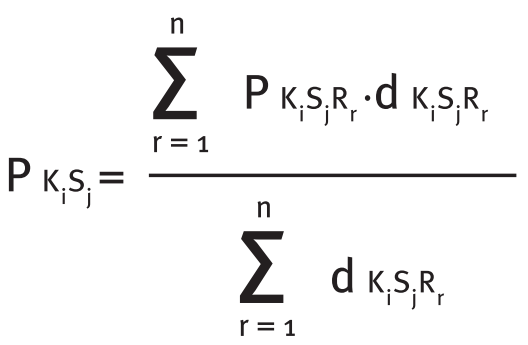

where

$\mathrm{P}_{\mathrm{KiSj}}$ is achieved percentage evaluation of " $j$ " sub-criterion in "i" criterion $r=1,2 \ldots n-$ number of requirements in criterion $\mathrm{K}_{\mathrm{i}}$ and subcriterion $\mathrm{S}_{\mathrm{i}}$, $\mathrm{d}_{\mathrm{KiSjRr}}$ is coefficient of importance for “ $r$ ” requirements of " $j$ ” sub-criterion in "I" criterion

Each of the criterions of the EFQM model has a defined maximum point value which can be achieved. It is evenly distributed among the individual subcriteria. The resulting number of points for the sub-criterion we obtain by multiplying of the achieved percentage value by maximum number of points. Generally we can for any criterion express:

$B_{s}=B_{\max } \cdot \frac{P_{s}}{100}$

where

$B_{S}$ is achieved score in evaluated sub-criterion

$B_{\max }$ is maximum score which can be in a given sub-criterion obtained

$\mathrm{P}_{\mathrm{S}}$ is achieved percentage evaluation for given sub-criterion

The resulting score for each criterion is the sum of achieved point value of its individual sub-criteria. The total achieved point value concerning the enablers is the sum of achieved points for criterion 1 to 5 . The maximum possible score can be 500 points (see enablers - Figure 1).
Electronic evaluation of the proposed solution

Electronic solution of proposed evaluation system is realized by using Microsoft Excel Program. The aim was to design and develop an automated system using computer technology, which would on the basis of defined requirements in electronic manual and in evaluation system allow easy, fast and comfortably realize evaluation of business per-formance and effectiveness, as well as clear and understandable display output of the evaluation process. Entering of inputs is handled through a questionnaire form, by selection of predefined options from "drop down menu" (dropdown list). The user does not perform any calculations, nor inscribe the input values. The results are updated immediately after any change in input data. The selected values the user can change at all time during the evaluation process (see Figure 4). Sheets "enablers" (see Figure 5) and "results" (see Figure 6) clearly show achieved percentage scores for each sub-criteria and requirements, and from these values is automatically calculated score for sub-criteria, and all criteria of "enablers" and "results" sections. Changes of point values are automatically transferred to the sheet EFQM - assessment, in which is a graphical view of the structure of the EFQM model with the nine criteria and the corresponding percentage and scoring for each of them for the "enable" and "result" part and also total assessment of all criteria.

\section{Application of the proposed}

methodology and manual into construction company

Application of the proposed methodology and the electronic manual was made for a construction company in Slovakia. During our cooperation we offered to the company basic training process concerning the EFQM model development and application and electronic manual for self-evaluation according to EFQM model criteria. Process of self-evaluation was realized using our software for automated evaluation quality management level in company according to EFQM model criteria. By application of the higher described methodology and electronic manual and the company during 1 year showed improvement in all criteria of the EFQM model (see Figure 7). Our cooperation will continue and we assume more dramatic improvement next 1-2 years after implementation next actions especially in production process.

\section{Relation Between Efqm Model And Corporate Social Responsibility}

EFQM model corresponds also with other philosophies like TQM (Oakland, 2003), Kaizen, Reengineering (Hammer and Champy, 1993) and Corporate Social Responsibility (STN ISO 26000, 2011).

Corporate Social Responsibility (CSR) is most often defined by the definition of the European Commission as a concept whereby companies integrate their social and environmental concerns in their business operations and in their interaction with stakeholders on a voluntary basis (European Commission, 2001). Socially responsible organizations focus not just on generating profits and economic growth but also take into account the social and environmental aspects of its activities. These three priorities (economic efficiency, environmental responsibility, social responsibility for employees, but also for society as a whole) can also be designated by the term "triple-bottom-line" respectively as a strategy $3 \mathrm{P}$ (People, Planet, Profit).

Construction organizations in the performance of their business activities are not isolated units, acting in a temporal and spatial reality and their responsible behaviour should focus on meeting and development of all three areas of CSR: (Gašparíková, 2012)

1. Economic responsibility that results from the existence of the 

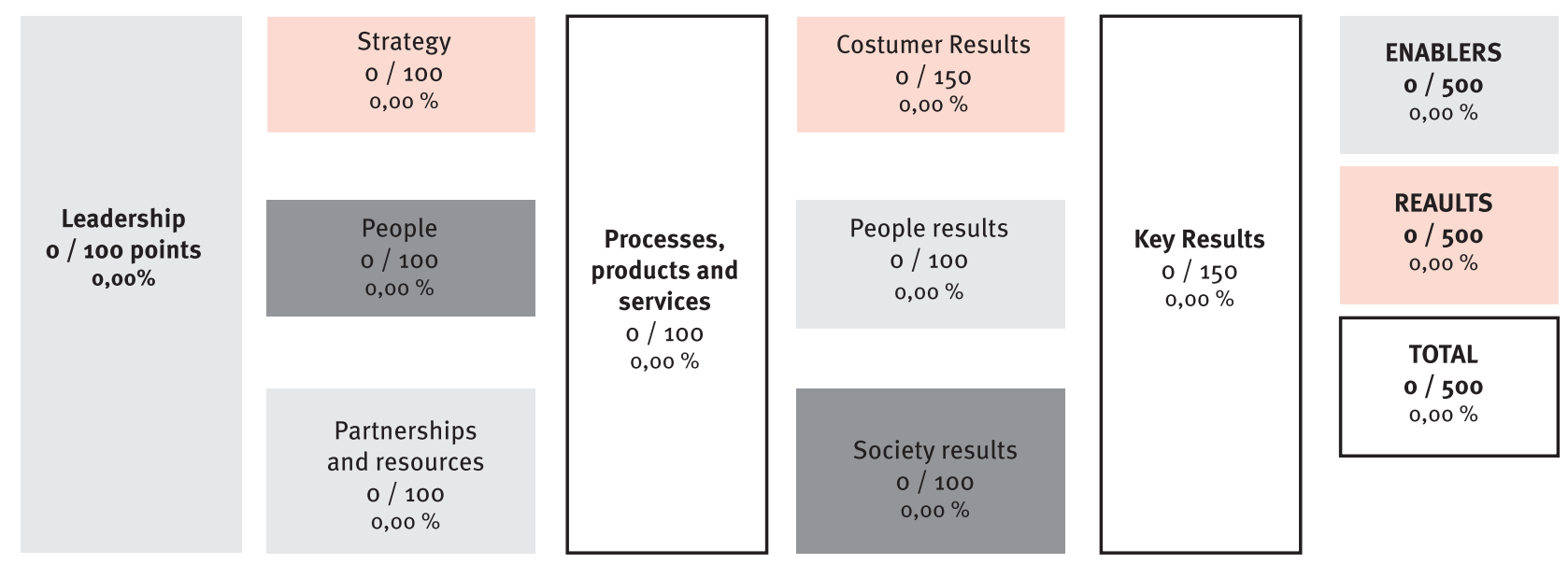

Table 4. Software illustration of EFQM model basic structure (starting level of criteria evaluation)

(Source: Gašparík, 2012)

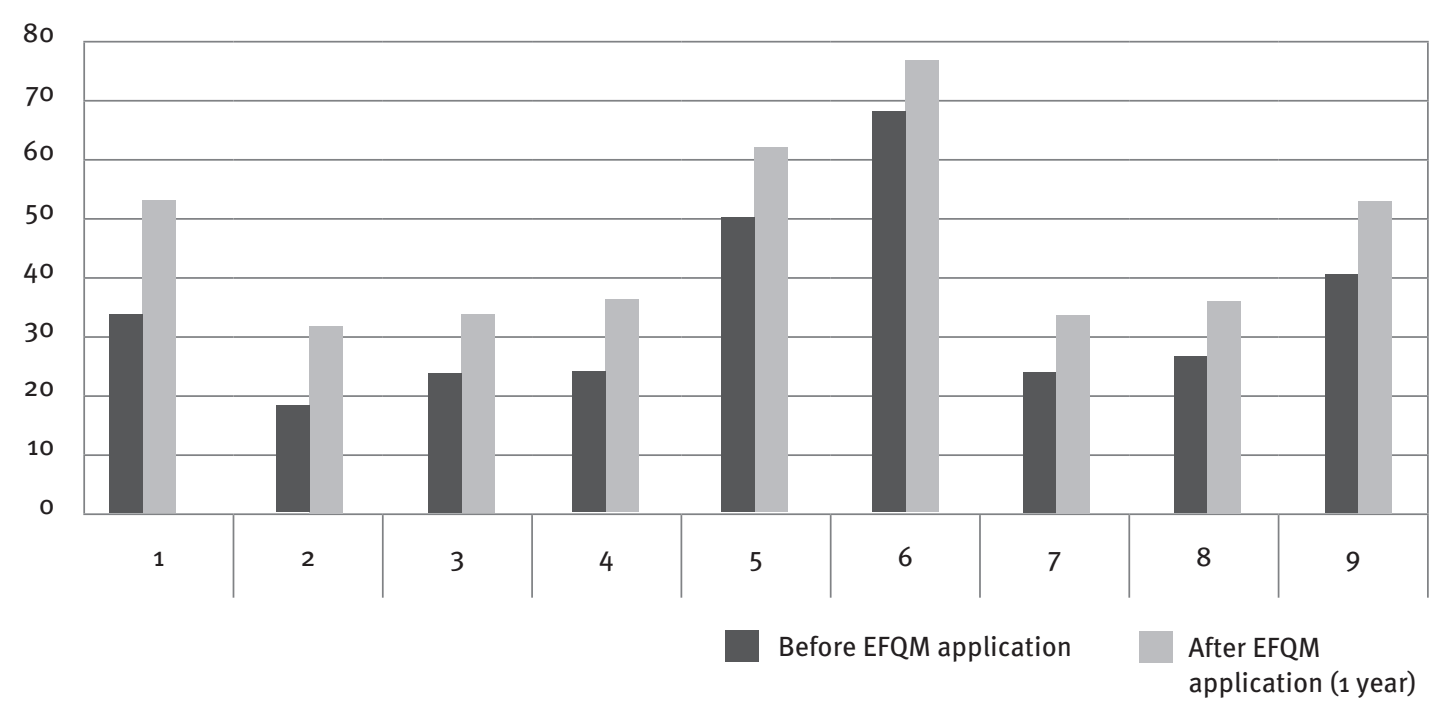

\section{Legend to Figure 7:}

1 - Leadership 2 - Policy and strategy 3 - People (employees)

4 - Partnership and resources 5 - Processes, products and services

6 - Customer results 7 - People results 8 - Society results 9 - Key results

construction organization in the market. It is a responsibility for the correct behaviour and interactions with other participants in the process of preparation and construction (investors, builders, designers, building contractors, etc.) and for the quality, productivity, efficiency and ability to create new value for building users (customers).
2. Environmental responsibility, aimed at minimizing the impact of construction activities on the environment in all directions (reduced consumption of energy and raw materials, reduction of emissions, waste minimization and separation, recycling of materials, prevention of contamination of water and soil, minimizing the negative effects of
Figure 7. Evaluation of EFQM model in construction company before model application and after 1 year (Source: Gašparík, 2012) noise and vibration on site and the surroundings, the protection of green, etc.)

3. Social responsibility on the one hand, for the health, safety, motivation, training of the employees, but on the other hand, the responsibility of construction organization to the community and society as a whole. Each area of CSR contains a lot of 


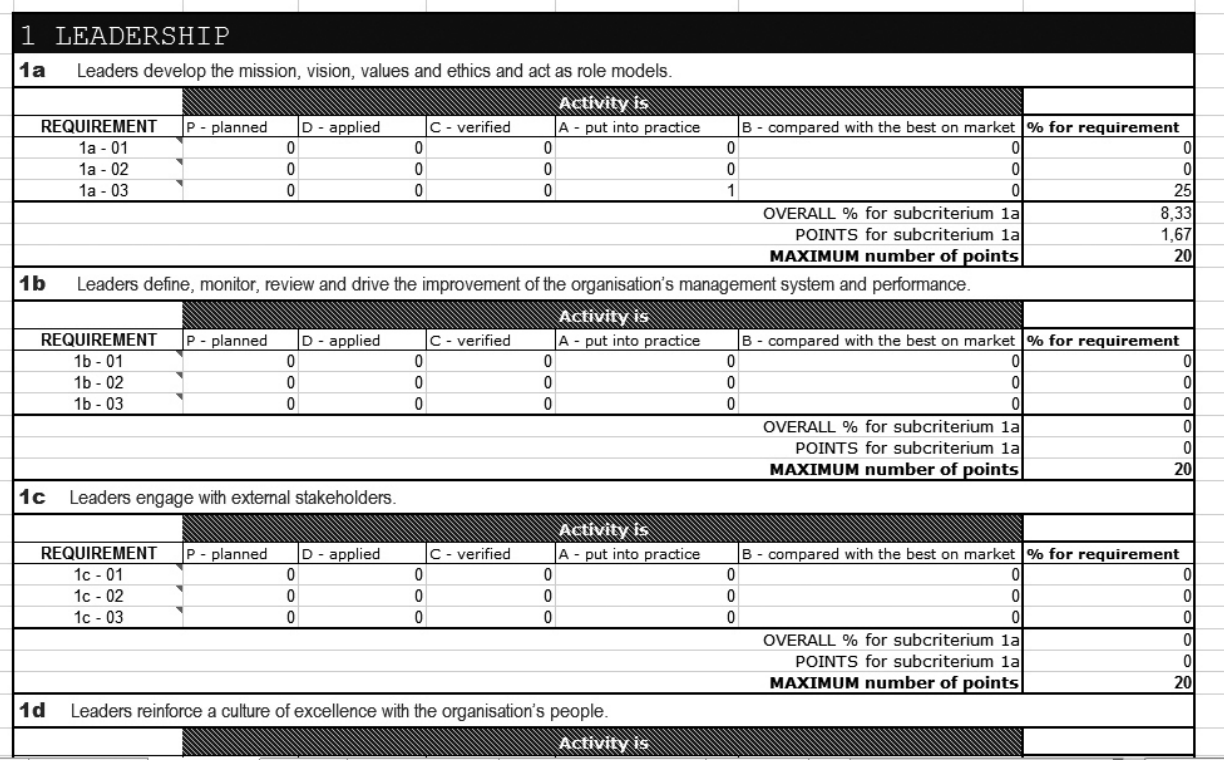

Figure 5. Software illustration of EFQM model part "enablers"

(Source: Gašparík, 2012)

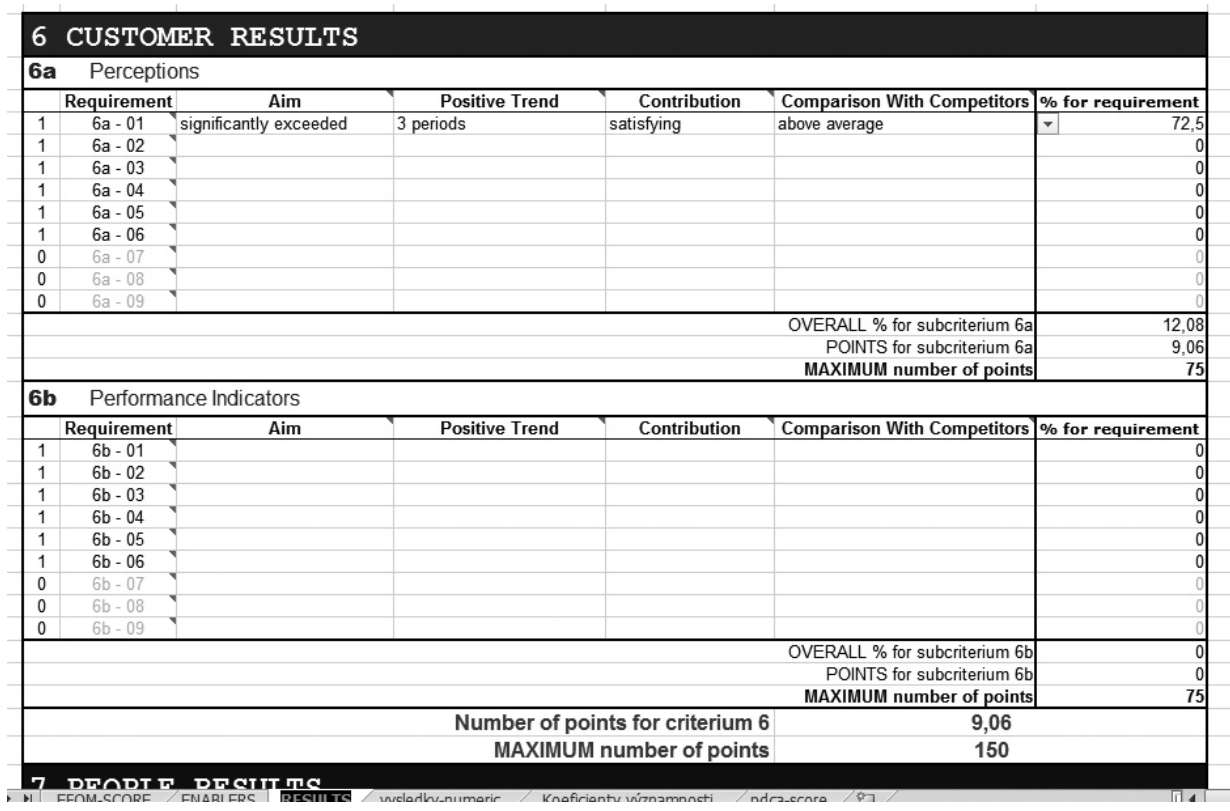

Figure 6. Software illustration of EFQM model part „results“

(Source: Gašparík, 2012)

activities and actions, from which the organization chooses the majority of their focus, or by knowledge of the needs and requirements of the stakeholders.

The EFQM Framework for CSR is based on the EFQM Excellence Model. It is therefore not a new Excellence Model, but a framework that provides guidelines on how to identify, improve and integrate the social, environmental and economic impacts of its operations into policy and strategy and the day-to-day management of an organization, taking all stakeholders onto account. The Framework is divided into the same nine criteria as the Excellence Model. The Enabler criteria focus on stakeholder 
engagement and dialogue, while the Result criteria focus on perception and performance CSR results. Each criterion is the divided into areas of interest, with guidance points in each of these areas. Automated systems of criteria evaluation in EFQM model could be used also for evaluation of CSR maturity in order to identify the strengths they should build on and the areas where they need to focus improvement. To gain maximum benefit, the output from such Self-Assessment exercises should be integrated into the normal strategy formulation and planning processes of the organization. Furthermore, using the Framework for CSR reporting will help an organization to optimize the use of available information together with a clear and simple approach for reporting.

\section{Conclusion}

Model EFQM is useful to implement after development and implementation of Quality Management System (QMS) according to ISO 9001. QMS represents very good basis for application of higher quality management philosophy, like TQM, KAIZEN or model EFQM. Research work described at this contribution results in the form of its own methodology and electronic manual allows to construction organizations effectively introduce and implement EFQM model requirements to practice in a relatively short period of time with aim to constantly improvement its performance towards excellence.

Defined methodology suggests and explains the sequence of steps towards EFQM model applying the electronic manual describes all of EFQM model sub-criteria and provides concrete suggestions and solutions to meet them. The part of manual there is also automated electronic assessment system for construction organizations which was verified in real company. Application of the methodology and manual enables in a short time to evaluate company quality management level and to identify opportunities for continually quality improvement.

The main results of our research activity are:

- creation of a new electronic manual for implementation and evaluation of EFQM model criteria and sub-criteria in construction company,

- the definition of mathematical models for automated evaluation of EFQM model criteria,

- the proposal of own software for automated evaluation of quality management level for company using EFQM model,

- continually improvement of construction company quality management level in all areas of its activities.

Model EFQM is an effective tool for continual improvement of organization quality, which leads not only to higher level of quality, but also to customer satisfaction, success at national and world market and to increasing the culture of whole organization.

\section{References}

Bendell, T. (1993), Benchmarking for Competitive Advantage, Longman, London.

EFQM. (2003), Assessing for Excellence: A practical Guide for Self-assessment, EFQM, Brussels.

European Commission. (2001), “Green Paper: Promoting a European Framework for Corporate Social Responsibility", (accessed 8 November 2012), available at: http://eur-lex. europa.eu/LexUriServ/site/en/com/2001/ com2001_0366eno1.pdf.

Gašparík, J. and Gašparík, M.(2012), Automatizovaný systém hodnotenia kvality výrobnej organizácie podla modelu EFQM, Edition TRIBUN EU, Brno.

Gašparík, J. and Búciová, M. (2011), “Higher levels of quality management in construction companies", in Organization, Technology and Management in Construction Proceedings from 1oth International Conference, vol. 40, no. 2, pp. 206-215.

Gašparíková, V. (2012), “Spoločenská

zodpovednost’ stavebnej organizácie v zmysle požiadaviek normy ISO 26000:2010", in IX. International Scientific Conference of Faculty of Civil Engineering [CD-ROM], Košice.
Hakes, C. (2007), The EFQM Excellence Model to Assess Organizational Performance: A Management Guide, Zaltbommel: Van Haren Publishing.

Hammer, M. and Champy, J. (1993),

Reengineering the corporation: A manifesto for business revolution, Harper Collins Publisher Inc., New York.

JUSE. (2003), Deming Prize Criteria. JUSE, Tokyo. Levicki, C. (1998), Leadership Gene, F.T. Management, London.

NIST. (2003), The Malcolm Baldridge National Quality Award Criteria, NIST, Gaithersburg.

Oakland, J.S. (2003), Total Quality Management, Elsevier Ltd., Oxford.

Paulová, I. et al. (2008), Metódy zlepšovania efektívnosti a účinnosti TQM, STU, Bratislava.

Porter, L.J. and Tanner, S.J. (2004), Assessing Business Excellence: A Guide to Business Excellence and Self-assessment, Butterworth-Heinemann, Burlington.

Porter, L.J. et al. (1998), Evaluating the European Quality Award Model for Self-Assessment, CIMA, London.

STN ISO 26000:2011, Usmernenie k spoločenskej zodpovednosti.

Zairi, M. (1998), Effective Management of Benchmarking Projects, ButterworthHeinemann, Oxford. 